\title{
SISTEM KEKERABATAN MASYARAKAT BALI DALAM NOVEL “TARIAN BUMI” KARYA OKA RUSMINI (KAJIAN ANTROPOLOGI SASTRA)
}

\author{
Jafar Lantowa \\ Program Studi Pendidikan Bahasa dan Sastra Indonesia, \\ Universitas Negeri Gorontalo, Indonesia \\ E-mail: jafar_lantowa@yahoo.com \\ Zilfa A. Bagtayan \\ Program Studi Pendidikan Bahasa dan Sastra Indonesia, \\ Universitas Negeri Gorontalo, Indonesia \\ E-mail: butterfly_blackwhite@yahoo.com
}

\begin{abstract}
THE KINSHIP SYSTEM OF THE BALINESE

FROM THE NOVEL “TARIAN BUMI” BY OKA RUSMINI (A LITERARY ANTHROPOLOGY STUDIES)
\end{abstract}

\begin{abstract}
This study aims to describe the kinship system of Balinese from the novel Tarian Bumi by Oka Rusmini which uses literary anthropology approach. In analyzing the cultural elements particularly the kinship system of the Balinese in the novel, this study uses descriptive, interpretative method by presenting it in description technique. The data were collected from reading and note-taking technique, and these were further analyzed using literary anthropology approach with content analysis model. Content analysis was done through inference, analysis, validity, and reliability. The results reveal that the Balinese practice the patrilineal and one-caste kinship system. This relationship is clearly illustrated by Telaga, a descendant of Brahmin strata, who married to a Sudra man.The marriage brought in disgrace, and a catastrophe for the family. Telaga opposed the one-caste marriage system by marrying a man who was not a descendant of the Brahmins. As a result, Telagawasexpelledfrom her'Dadia' (Brahmin's family temple). Telaga followed her husband as a Sudra woman along with her descendants because of the patrilineal kinship system that governs the lives of the Balinese. In conclusion, the kinship system of the Balinese from the novel "Tarian Bumi" by Oka Rusmini is patrilineal, which turns to be a tradition for the Balinese in their marriage.
\end{abstract}

Keywords: kinship system, Balinese, Literary anthropology, novel

\section{PENDAHULUAN}

Sastra merupakan produk budaya yang merepresentasikan gejala kebudayaan melalui sarana bahasa sastra yang estetis. Koentjaraningrat merumuskan kebudayaan sebagai keseluruhan sistem gagasan, tindakan, dan hasil karya manusia dalam rangka kehidupan masyarakat yang dijadikan milik dari manusia dengan belajar
(Koentjaraningrat, 2002:180). Sastra sebagai bagian dari kebudayaan yang mencerminkan unsur budaya lokal yang perlu dipahami melalui kajian terhadap sastra warna lokal sehingga dapat memperkaya wawasan budaya pembaca. Salah satu unsur budaya tersebut adalah sistem kekerabatan yang mencerminkan lokalitas setiap daerah. 
Meyer Fortes (dalam Hermaliza, 2011: 123-124) mengemukakan bahwa sistem kekerabatan suatu masyarakat dapat dipergunakan untuk menggambarkan struktur sosial dari masyarakat yang bersangkutan. Kekerabatan adalah unitunit sosial yang terdiri dari beberapa keluarga yang memiliki hubungan darah atau hubungan perkawinan (genealogis). Anggota kekerabatan terdiri atas ayah, ibu, anak, menantu, cucu, kakak, adik, paman, bibi, kakek, nenek, dan seterusnya. Dilihat dari alur peran dan fungsi anggota keluarga dalam masyarakat, sistem kekerabatan dapat dibedakan menjadi patrilineal dan matrilineal. Patrilineal adalah suatu adat masyarakat yang mengatur alur keturunan yang berasal dari pihak ayah. Sebaliknya, matrilineal adalah suatu adat masyarakat yang mengatur alur keturunan yang berasal dari pihak ibu (Hermaliza, 2011:123-124).

Dalam novel Tarian Bumi karya Oka Rusmini ada penggambaran tentang hubungan perkawinan pada masyarakat Bali. Novel ini termasuk sastra warna lokal sebagaimana yang dikemukakan oleh Michael Bodden (dalam Rusmini, 2013:179) bahwa novel Tarian Bumi karya Oka Rusmini mengandung unsurunsur yang mengaitkannya pada arus baru dalam fiksi warna daerah. Warna lokal yang tampak dalam novel ini terutama pada sistem kekerabatan masyarakat Bali melalui hubungan perkawinan.

Perkawinan merupakan sebuah bentuk kekerabatan yang penting dalam kehidupan orang Bali, karena dengan perkawinan tersebut akan membentuk sebuah kekerabatan yang terjalin dalam sebuah keluarga. Bagus (dalam Koentjaraningrat, 2010: 294) menguraikan bahwa menurut anggapan adat lama yang amat dipengaruhi oleh sistem klen-klen (dadia) dan sistem kasta (wangsa), maka perkawinan itu sedapat mungkin dilakukan di antara warga se-klen, atau setidaknya antara orang-orang yang dianggap sederajat dalam kasta. Orang-orang se-Klen di Bali adalah orang-orang yang setingkat kedudukannya dalam adat dan agama, dan demikian juga dalam kasta, sehingga dengan berusaha untuk kawin dalam batas klen-nya, terjagalah kemungkinankemungkinan akan keteganganketegangan dan noda-noda keluarga yang akan terjadi akibat perkawinan antar-kasta yang berbeda derajatnya. Dalam hal ini terutama harus dijaga agar anak wanita dari kasta yang tinggi jangan sampai kawin dengan pria yang lebih rendah derajat kastanya, karena suatu perkawinan serupa itu akan membawa malu kepada keluarga serta menjatuhkan gengsi seluruh kasta dari anak wanita itu, sehingga jika terjadi hal 
seperti itu maka wanita itu akan keluar dari dadianya. Pernyataaan melalui tulisan Bagus tersebut, tergambar dalam novel Tarian Bumi melalui tokoh utama yakni Telaga yang menentang adat dengan menikah yang tidak sekasta dengannya, sehingga ia menghadapi berbagai konflik dengan keluar dari sanggar keluarga Brahmana. Permasalahan tersebut mengarah kepada sistem kekerabatan masyarakat Bali yang ditentang oleh tokoh utama, sehingga menarik untuk dikaji.

Dalam mengungkap sistem kekerabatan masyarakat Bali tersebut, peneliti menggunakan pendekatan antropologi sastra. Dalam pendekatan antropologi sastra terdapat teori representasi budaya sebagai bentuk penggambaran budaya dalam novel. Dalam menguraikan representasi budaya dalam novel, peneliti memanfaatkan konsep Koentjoroningrat mengenai unsur-unsur budaya terutama unsur sistem kekerabatan dalam novel. Pendeskripsian sistem kekerabatan ini menarik dilakukan dalam novel karena untuk memperluas wawasan budaya pembaca yang tercermin dalam sastra Indonesia warna lokal. Keunikan yang ada dalam novel Tarian Bumi karya Oka Rusmini terdapat pada penggambaran lokalitas daerah Bali yang terkenal dengan sistem patriliniel. Keunikan lainnya terdapat pada cirri khas novel ini sebagai novel warna lokal Bali yang dapat membuka wawasan pembaca tentang kehidupan orang Bali terutama pada sistem kekerabatan masyarakat Bali.

\section{KAJIAN PUSTAKA}

Menurut Ratna analisis
antropologis adalah usaha untuk
mencoba memberikan identitas
terhadap karya tersebut, dengan
menganggapnya sebagai mengandung
aspek tertentu, dalam hubungan ini ciri-
ciri kebudayaannya. Ciri-cirinya, di
antaranya: memiliki kecenderungan ke
masa lampau, citra primordial, citra
arketipe. Ciri-ciri yang lain misalnya
mengandung aspek-aspek kearifan lokal
dengan fungsi dan kedudukannya
masing-masing, berbicara mengenai
suku-suku bangsa dengan
subkategorinya, seperti; trah, klen, dan kasta (Ratna,2011:31, 39-40). Antropologi sastra dalam pandangan Poyatos adalah ilmu yang mempelajari sastra berdasarkan penelitian antarbudaya. Penelitian budaya dalam sastra tentu diyakini sebagai refleksi kehidupan (Endraswara, 2015: 3-4). Aspek-aspek antropologis dalam karya sastra, meliputi sistem pengetahuan, adat-istiadat, sistem kekerabatan, sistem peralatan hidup dan teknologi, mata pencaharian, kesenian, serta sistem kepercayaan dan agama 
(Sudikan, 2007: 6). Sistem kekerabatan merupakan salah satu unsur-unsur budaya sebagaimana yang dikemukakan oleh Koentjaraningrat (2015: 165) bahwa unsur budaya terdiri atas tujuh bagian di antaranya adalah sistem kekerabatan. Sistem kekerabatan berkaitan dengan pengertian tentang perkawinan dalam suatu masyarakat karena perkawinan merupakan inti atau dasar pembentukan suatu komunitas atau organisasi sosial. Perkawinan diartikan sebagai penyatuan dua orang yang berbeda jenis kelamin untuk membagi sebagian besar hidup mereka bersama-sama. Terdapat jenis kekerabatan yang menganut prinsip patrilineal atau menganut garis keturunan ayah atau pihak laki-laki dan prinsip matrilineal atau menganut garis keturunan dari pihak ibu atau perempuan serta prinsipprinsip kombinasi seperti kekerabatan ambilineal dan bilineal. Masyarakat yang bersifat patriarkal dapat dijumpai di berbagai tempat karena mayoritas masyarakat mempraktikkan prinsip keturunan ini (Siany dan Catur, 2009: $62,64)$.

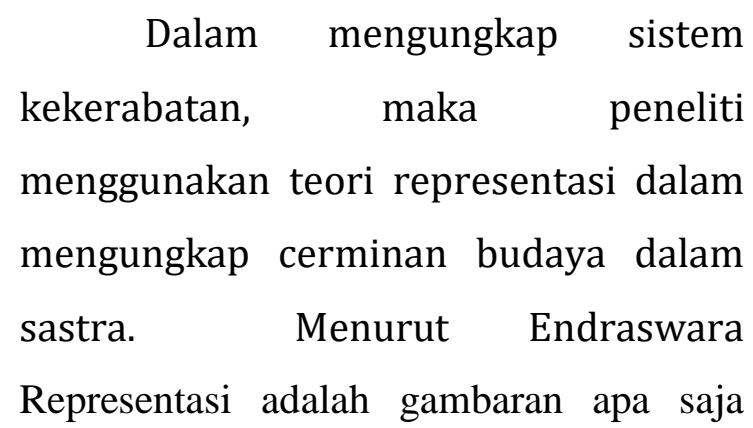

yang ada dalam sastra. Gambaran dapat disebut citra. Sastra akan mencitrakan kehidupan manusia. Peneliti antropologi sastra adalah orang yang membawa teropong untuk melihat apa yang ada dalam sastra dan apa yang ada dibalik realitas teks. Teks sastra biasanya menyembunyikan makna. Derajat persembunyian makna itulah yang apabila terungkap akan mereprsentasikan makna. Jadi, representasi adalah pemaknaan atas dasar fenomena teks. Representasi adalah pencerminan yang dapat menangkap segala hal Itentang aspek budaya dalam sastra (Endraswara, 2015: 28). Jadi, dalam penelitian ini, digunakan pendekatan antropologi sastra dalam melihat representasi budaya dalam novel Tarian Bumi karya Oka Rusmini.

\section{METODE PENELITIAN}

Dalam mengungkap representasi budaya terkait dengan sistem kekerabatan masyarakat Bali dalam Novel Tarian Bumi karya Oka Rusmini, peneliti menggunakan metode deskriptif interpretatif. Data penelitian berupa kutipan kalimat yang merepresentasikan sistem kekerabatan masyarakat Bali yang bersumber dari novel Tarian Bumi karya Oka Rusmini cetakan kedua tahun 2013 dengan jumlah 175 halaman. Pendekatan yang digunakan dalam penelitian ini adalah pendekatan antropologi sastra dengan memfokuskan pada penelitian teks 
sastra yang meneliti refleksi sastra sebagai pantulan budaya. Teknik pengumpulan data dilakukan dengan teknik baca dan catat. Novel Tarian Bumi dibaca secara cermat, teliti, dan berulang-ulang untuk menemukan sistem kekerabatan yang terkandung di dalamnya baik yang implisit maupun eksplisit. Data yang telah ditemukan dianalisis menggunakan pendekatan antropologi sastra dengan model analisis konten. Analisis konten dilakukan melalui tahap inferensi, analisis, validitas dan reliabilitas. Inferensi bertumpu pada makna simbolik melalui pengkodean dengan berdasar pada teori representasi dan dianalisis dengan metode hermeneutik. Cara pertama ini dilakukan dengan pencatatan terhadap kalimat yang mengandung simbol representasi sistem kekerabatan masyarakat Bali. Catatan tersebut diberi kode kemudian dianalisis. Selanjutnya dilakukan validitas semantik dengan mengukur tingkat pemahaman makna dan reliabilitas yang dipakai adalah keakuratan, yakni penyesuaian hasil penelitian dengan kajian pustaka dan reliabilitas interrater (antartim peneliti). Jadi, setelah diberi pengkodean, dianalisis, kemudian hasil analisis diukur dengan cara menyesuaikan dengan kajian pustaka dan diskusi antartim peneliti serta pembimbing dalam mengukur pemahaman makna terkait dengan representasi sistem kekerabatan masyarakat Bali dalam novel Tarian Bumi Karya Oka Rusmini.

\section{HASIL DAN PEMBAHASAN}

Sistem kekerabatan masyarakat Bali dapat dilihat dari hubungan perkawinan yang mengutamakan pada sistem klen dan sistem kasta, sehingga harus tunduk pada tradisi yakni dengan menikah pada yang sekasta agar tidak terjadi berbagai permasalahan yang menjadi aib keluarga. Pada perkawinan ini, khususnya pada pihak perempuan yang memiliki kasta yang lebih tinggi harus menikah dengan yang sekasta agar tidak membawa malu bagi keluarga besarnya. Hal ini terjadi pada tokoh utama yakni Ida Ayu Telaga Pidada yang menjadi tokoh sentral dalam novel Tarian Bumi karya Oka Rusmini.

"Kau adalah harapan Meme,
Tugeg. Kelak, kau harus menikah
dengan laki-laki yang memakai
nama depan Ida Bagus. Kau harus
tanam dalam-dalam pesanku ini.
Sekarang kau bukan anak kecil
lagi. Kau tidak bisa bermain bola
lagi. Kau harus mulai belajar
menjadi perempuan keturunan
Brahmana. Menghapal beragam
sesaji, juga harus tahu bagaimana
mengukir janur untuk upacara"
(Rusmini, 2013:67). Data tersebut menggambarkan bahwa keinginan dari ibu Telaga tercermin melalui pesannya untuk menikahkan Telaga dengan laki-laki 
sekasta yakni berketurunan Brahmana dengan ditandai nama depan Ida Bagus. Harapan ibunya ini menyiratkan kepada sistem kekerabatan patrilineal yang harus dipertahankan demi menjaga nama baik keluarga. Keinginan ibunya ini diperkuat lagi dengan data berikut.

Dia berharap kelak seorang Ida Bagus dari keluarga terhormat akan meminang putrinya. Sebuah pernikahan yang agung dan besar. Telaga akan dipinang, diarak

para sisia dan masyarakat Desa. (Rusmini, 2013:67).

Namun Ibu Telaga tidak seperti yang dibayangkan karena anaknya tidak ingin menikah dan mengalami seperti yang dialami oleh ibu dan neneknya yang penuh dengan penderitaan karena hanya mengutamakan nilai-nilai kebangsawanan tanpa ada rasa cinta yang tulus. Ketika ibunya berambisi untuk menikah dengan laki-laki Brahmana untuk menaikan statusnya sebagai perempuan terhormat yang ingin dihargai oleh kerabat dan Pernyataan Telaga dan dialog dengan ibunya tersebut menjadi gambaran dalam penolakan sistem kekerabatan yang telah menjadi pakem bagi masyarakat Bali. Telaga begitu berani menentang aturan yang justru baginya adalah sebuah beban yang harus ditanggung bagi perempuan Bali yang berketurunan Brahmana. Penolakan Telaga terhadap sistem tampak pula pada perasaan cintanya masyarakat lingkungannya. Namun, sebaliknya keinginan itu bertolak belakang dengan realitas yang ia hadapi, justru ia hanya mengalami berbagai konflik bersama suaminya berupa penghianatan dan penyiksaan sang suami terhadap ibunya. Begitu juga dengan neneknya yang hanya tunduk pada tradisi harus menikah dengan lakilaki Brahmana, justru mendapat penderitaan. Telaga tidak ingin itu terjadi pada dirinya. Hal tersebut tampak pada data berikut.

Perempuan? Bagaimana rasanya mengenakan jubah baru itu? Apakah nasib Telaga akan seperti Nenek? Ataukah Ibu?

"Kenapa begitu banyak aturannya, Meme?"

"Ini bukan aturan. Ini pakem leluhur yang harus dipatuhi kalau Tugeg ingin bahagia."

"Tugeg tidak senang menjadi dewasa?"

"Tidak. Tiang tidak ingin mencintai laki-laki!"

(Rusmini, 2013:67, 69, 73)

pada Wayan Sasmitha yang merupakan lelaki Sudra, sehingga bagi keluarga Telaga ini menjadi awal dari malapetaka yang akan menimpa Telaga. Perasaan ini berawal dari dunia tari yang dilakukan oleh Telaga tanpa pengawasan dari ibunya. Padahal Telaga selalu berada pada pengawasan dan keinginan Ibu, namun dunia tari ini di luar dari pengawasan sehingga memunculkan 
perasaan cinta Telaga kepada lelaki yang bukan sekasta dengannya.

"Luh Sekar bagi Telaga adalah perempuan yang sangat keras kepala. Keinginan-keinginannya adalah harga mati. Tidak ada orang yang bisa membelokkannya.

Telaga merasa cukup dewasa untuk menolak keinginankeinginan ibunya. Makin hari perempuan itu makin menjerat dan mengikatnya erat-erat. Perempuan itu juga tidak membiarkan Telaga berpikir untuk hidupnya sendiri. Apa pun selalu di bawah pengawasannya dan berdasarkan keinginannya.

"Tapi ada satu dunia yang tidak bisa dimasuki ibunya: Telaga masuk sekehe tari. Masuk sekehe tari berarti harus memenuhi syarat-syarat yang diajukan sekehe itu. Telaga harus menari kapan pun diperlukan. Tak seorang pun tahu bahwa dalam sekehe itu ada semesta lain yang membuat Telaga hidup."

"Semesta itu bernama Wayan Sasmitha, mahasiswa seni lukis tingkat akhir. Lukisannya banyak, dan dia sering berpameran ke luar negeri. Telaga menyukai laki-laki itu sejak masih kanakkanak. (Rusmini, 2013:110).

Bermula dari sekehe tari, perasaan cinta kepada lelaki oleh Telaga pun muncul. Perasaan cinta itu justru kepada lelaki Sudra yang tidak sesuai dengan harapan keluarganya sebagai keturunan Brahmana. Bagi keluarga Telaga, perasaan cinta ini menjadi awal malapetaka karena menjadi aib keluarga. Bukan hanya Telaga yang memiliki perasaan cinta tersebut, tetapi juga Wayan Sasmita yang menganggap
Telaga adalah suatu anugerah bagi kehidupannya, namun ia sadar bahwa ia tidak pantas untuk memiliki Telaga sebagai perempuan keturunan Brahmana.

"Wayan berkata pada dirinya sendiri. Sering kali dia menyadarkan dirinya, bahwa Telaga tidak mungkin bisa didapatkannya. Bisa menyentuh perempuan itu saja sudah suatu anugerah.

Setiap ada perayaan di desa, Wayan dan Telaga selalu menari. Pada saat seperti itu, Wayan merasa seluruh semangatnya mengalir begitu deras. Keberanian yang dia tidak pernah tahu dari mana datangnya. Bersama Telaga kehidupan lebih memiliki warna yang tegas. Telaga juga lebih mengganggu konsentrasinya dibanding ide-idenya dalam melukis. Setiap berhadapan dengan Telaga, Wayan selalu gugup. (Rusmini, 2013:117)

Dalam hati Wayan sebagai lelaki, memiliki perasaan cinta yang dalam terhadap Telaga, namun sebagai lelaki Sudra, ia menyadari bahwa Telaga tidak pantas baginya, sehingga cukup bersama Telaga sudah merupakan kebahagiaan tersendiri baginya. Cinta keduanya ini dibatasi oleh aturan adat yang berlaku bagi masyarakat Bali melalui hubungan kekerabatan antarkasta, sehingga menjadi hambatan dalam hubungan cinta mereka. Sementara Luh Sekar tetap menginginkan Telaga untuk menikah dengan lelaki Brahmana, sehingga 
berusaha mengajak lelaki keturunan Brahmana untuk bertamu dan menyuruh Telaga untuk menemani mereka.

"Telaga benar-benar lelah menghadapi ibunya. Suatu hari dia undang Ida Bagus Adnyana untuk datang, dan membiarkan laki-laki itu masuk langsung ke kamar Telaga. Ibunya benarbenar aneh. Telaga jadi tidak habis pikir, apa yang ibunya inginkan dari laki-laki yang memiliki berpuluh homestay serta hotel di Kuta dan Ubud itu? Kenapa tidak ibunya saja yang menikah dengan laki-laki itu? Laki-laki yang telah menghamili teman baik Telaga, dan tidak berani bertanggung jawab Cuma karena perempuan itu perempuan Sudra! (Rusmini, 2013:122).

Data tersebut semakin mengindikasikan pada aturan yang dipegang teguh oleh ibunya dalam mencarikan pasangan untuk Telaga yang berdasarkan keturunan terhormat. Dalam data itu pun, tampak pada lelaki Brahmana yang tidak mau bertanggung jawab terhadap perempuan Sudra yang dihamili. Hal tersebut menggambarkan bahwa dalam tradisi Bali, sistem kekerabatan ditentukan oleh status yakni menikah dengan yang sederajat. Di balik penolakan sistem oleh Telaga, terdapat dorongan naluri Telaga terhadap lelaki Sudra yang begitu dicintainya, sementara lelaki itu pun begitu mencintai Telaga. Hal ini menjadi dasar pendobrakan sistem oleh Telaga dalam tradisi masyarakat Bali.

"Telaga menarik napas. Hampir semua perempuan di griya tertarik pada laki-laki itu. Termasuk dirinya. Sakit sekali mendengar perempuanperempuan itu bercerita tentang pengalamannya menyentuh tubuh Wayan. Laki-laki yang dicintainya sejak umur sepuluh tahun!Sampai hari ini, cinta itu tidak berkurang satu senti pun. Tidak juga bergeser. Dia tetap terjaga dengan baik, bahkan makin hari makin subur saja. Rasanya cinta Telaga pada Wayan membuat Telaga hampir meledak. Kerinduanya pada lakilaki itu telah sampai di ubunubun. Mengaliri seluruh sungai dan laut dalam tubuhnya. (Rusmini, 2013:130).

Kekuatan cinta antara Telaga dan Wayan mendorong keberanian mereka untuk melawan sistem yakni dengan melangsungkan pernikahan meskipun berbeda kasta. Keberanian inilah menjadi penyebab Telaga untuk membicarakan niat ini kepada ibu Wayan. Namun, seperti yang sudah terjadi dalam tradisi, permintaan Telaga dan Wayan mendapat penolakan dari ibu Wayan sebagai perempuan Sudra yang meyakini dan berpegang teguh pada tradisi.

"Kau sadar siapa dirimu, Wayan? Kau sudah berpikir apa jadinya kalau kau menikah dengan Dayu Telaga? Ada apa dengan dirimu! Kau anak laki-laki satu-satunya milik Meme. Jangan buat masalah dengan orang-orang Griya." 
"Ternyata perempuan tua itu tidak berani menerimanya sebagai menantu. Seorang lakilaki Sudra dilarang meminang perempuan Brahmana. Akan sial jadinya bila Wayan mengambil Telaga sebagai istri. Perempuan Sudra itu percaya pada mitos bahwa perempuan Brahmana adalah surya, matahari yang menerangi gelap. Kalau matahari itu dicuri, bisakah dibayangkan akibatnya?"

"Wayan!Di mana otakmu. Kau akan mengambil junjunganmu sendiri? Orang yang seharusnya kita lindungi dan hormati. Keluarga kita hidup dari keluarga griya. Mereka yang menolong keluarga ini agar bisa tetap makan. Apa dosaku sehingga punya anak setolol kamu!" (Rusmini, 2013:136-137).

Data tersebut semakin memperjelas sistem kekerabatan yang sudah mengakar pada masyarakat Bali. Melalui penolakan dan pernyataan ibu Wayan, tampak sistem kekerabatan yang berdasarkan kasta harus dijunjung tinggi oleh masyarakat Bali. Sistem yang melarang perkawinan antar laki-laki Sudra dengan perempuan Brahmana. Perempuan Brahmana dianggap suci oleh masyarakat Sudra sehingga mitos yang berkembang bagi perempuan Sudra, yakni akan sial jika melanggar sistem tersebut sehingga hal tersebut menjadi penghalang cinta Telaga dan Wayan. Menurut Oka Rusmini dalam novel Tarian Bumi bahwa bagi masyarakat Bali, hubungan perkawinan antara Wayan dan Telaga adalah aib, sehingga membawa malapetaka dan aib bagi keluarga kedua belah pihak, sehingga Telaga harus keluar dari dadianya (kuil keluarga Brahmana).

"Meme perempuan kolot, Tugeg. Perempuan kampung. Meme tetap tidak bisa menerima hubungan ini. Aib!"

Luh Gumbreg merasa kesulitan hidupnya sudah mulai terbuka di depan mata. Dia akan menjadi pergunjingan orang. Setiap dia melakukan gerak, seluruh mata orang desa akan mengikuti geraknya. Bahkan Gumbreg yakin ketika bernapas pun ada mata yang mengikuti."

"Sakit sekali dadanya. Kesalahan apa yang telah diperbuatnya sehingga anak laki-laki kesayangannya berniat memasuki malapetaka yang akan terus dijunjungnya tinggi-tinggi? Gumbreg tidak bisa membayangkan apa yang akan dikatakan Jero Kenanga padanya. Perempuan itu pasti mengejek dengan sorot matanya yang tajam dan selalu penuh dengan kemarahan itu. Belum lagi tatapan orang-orang Sudra yang menyesali semua aib yang terjadi, Gumbreg menutup mata tuanya. Lelah, lelah sekali. (Rusmini, 2013:137-138.)

Bagi Luh Gumbreg, perkawinan antara Wayan dan Telaga menjadi penyebab penderitaan yang berkepanjangan yang akan dialaminya. Keyakinan terhadap tradisi tersebut, menjadi bentuk penolakan Luh Gumbeg terhadap hubungan mereka. Namun, karena kekuatan cinta mereka, perkawinan pun dilangsungkan dengan alasan kehamilan Telaga yang sudah 
lima bulan, sehingga mengharuskan mereka untuk menikah. Mendengar pernyataan kehamilan Telaga, Ibu Wayan, semakin sadar dan menerima Telaga sebagai menantunya. Perkawinan itu pun terlaksana dengan cara melarikan Telaga yang juga berdasarkan adat dalam masyarakat Bali. Pada umumnya, seorang pemuda Bali itu dapat memperoleh seorang isteri dengan dua cara, yaitu dengan cara meminang (memadik, ngidih) kepada keluarga seorang gadis, atau dengan cara melarikan seorang gadis (mrangkat, ngorod). Kedua cara itu berdasarkan adat (Bagus, 2010: 295). Cara kedua ini yang dilakukan oleh Wayan sebagai pemuda Bali untuk memiliki Telaga sebagai istri. Namun, bagi masyarakat Bali, terutama perempuan Brahmana yang diculik akan ada dampaknya berupa malapetaka yang akan menimpa kedua belah pihak. Hukuman adat bagi Telaga, ia harus keluar dari kebangsawanannya sebagai perempuan Brahmana. Ia sudah tidak dianggap lagi sebagai keturunan Brahmana sehingga semua perlengkapan sebagai keturunan bangsawan ditanggalkan demi mengejar cinta yang tulus bersama Wayan.

"Perkawinan itu berlangsung. Hidup Telaga jadi berubah total. Bangun pagi-pagi tidak ada pelayan yang menyiapkan segelas susu dan roti bakar. Yang ada hanya segelas air putih. Itu pun air putih kemarin. Telaga menguknya. Matanya sedikit berair."

"Telaga tahu, dua orang perempuan dalam rumah ini tidak mengharapkan kehadirannya. Mereka percaya kedatangan Telaga ke rumah mereka hanya membawa runtutan kesialan saja. Apalagi Telaga benar-benar tidak membawa satu butir berlian pun. Semua perhiasannya dia tinggalkan di Griya. Telaga juga tidak membawa pakaiannya, karena beranggapan akan sial jadinya bila semua barangnya dibawa. Barang-barang itu miliki Nenek, milik ibu. Kalau Telaga menikah dengan laki-laki Brahmana, keluarga besar akan membekali kepergiannya dengan barang-barang itu. Karena menikah dengan Wayan, tidak ada keluarga Griya yang datang membawa perangkat pakaian dan pergiasan untuk Telaga. Apalagi dia kawin tanpa pamit. ." "Telaga menikah tanpa orangtua. Saat ini dia hanya memiliki Wayan. Telaga percaya laki-laki itu bisa merawat tubuhnya, menjaga perasaanya. (Rusmini, 2013:146, 148).

Data tersebut menunjukkan risiko yang dihadapi oleh Telaga dalam melanggar sistem. Telaga menghadapi berbagai kesulitan hidup yang serba terbatas dan sangat sederhana. Begitu pula dengan berbagai ocehan ibu dan adik Wayan yang tidak suka dengan kehadiran Telaga. Kedatangan Telaga justru membawa sial bagi keluarga Wayan. Begitu juga dengan Telaga, yang harus lepas dari kebangsawananya 
sebagai perempuan Brahmana. Ia tidak lagi berpakaian sebagaimana perempuan Brahmana, semua ia tinggalkan demi cinta. Sebagai tradisi, sudah digambarkan pula bahwa pernikahan sekasta akan diberi jaminan hidup dengan persediaan bekal yang lengkap, namun karena tidak sekasta, maka risikonya tidak ada perangkat yang dibawa ke rumah Wayan.

Perkawinan beda kasta juga bagi perempuan Sudra akan mendatangkan kesialan. Hubungan antara Wayan dan Telaga begitu dibenci oleh ibu Wayan, sehingga dengan kematian Wayan kemarahan Luh Gumbreg semakin membuat Telaga merasa bersalah dan tertekan.

"Berkali-kali tiang berkata,
menikah dengan perempuan Ida
Ayu pasti mendatangkan
kesialan. Sekarang anakku mati!
Wayan tidak pernah mau
mengerti. Ini bukan cerita
dongeng. Ini kebenaran. Kalau
sudah begini jadinya aku harus
bicara apa lagi!” Luh Gumbreg
memukul dadanya. Menatap
Telaga tidak senang. (Rusmini,
2013:152).

Pernyataan Ibu Wayan menjadi bentuk kekesalan dan menyalahkan Telaga sebagai akibat dari kematian Wayan. Bagi Telaga, kematian Wayan karena sakit yang dialami sehingga Telaga kurang memercayai anggapan ibu Wayan. Kepercayaan ibu Wayan juga diperkuat oleh anggapan orang-orang
Griya yang merupakan masyarakat tempat tinggal ibu Wayan, bahwa kematian Wayan karena menikah dengan seorang Ida Ayu. Setelah kematian Wayan, Telaga semakin tersiksa dan kelaparan karena keterbatasan ekonomi. Namun, Telaga tetap menerima dan sabar menghadapi hingga hati Luh Gumbreg semakin luluh dan mulai bersahabat dengan Telaga. Dalam menghindari kesialan yang akan terjadi pada Telaga dan anak cucunya, maka Luh Gumbreg meminta Telaga untuk pamit pada ibunya dan melakukan upacara patiwangi.

"Dulu, ketika kau dikawini anak tiang, kau belum pamit ke griya. Kau juga belum melakukan upacara patiwangi. Aku ingin kau melakukan semua itu. Demi keluarga ini!" Suara Gumbreg miri perintah. (Rusmini, 2013:164).

Perintah Ibu Wayan tersebut berkaitan dengan sistem tradisi yang mengatur hubungan kekerabatan antar masyarakat Bali, terutama perkawinan tidak seksasta. Sebagaimana yang dialami oleh Telaga dan Wayan, yang seharusnya Telaga pamit pada keluarga dan mengikuti upacara demi menghindari malapetaka yang akan menimpa keluarga Luh Gumbreg terutama bagi Telaga dan anak-anaknya kelak. Permintaan itu dilakukan oleh Telaga dengan memberanikan diri untuk 
kembali ke tempat Ibunya untuk melakukan upacara tersebut.

"Setan apa yang membawamu kemari!" Suara dari dalam terdengar penuh amarah.

"Kenanga! Bagaimana pun juga Telaga anakmu."

"Tiang sudah lama tidak memiliki anak, Ratu. Sudah mati!" (Rusmini, 2013:168).

Pernyataan ibu Telaga merupakan bentuk penolakan terhadap kedatangan Telaga yang telah menikah dengan lelaki Sudra. Telaga sudah tidak dianggap lagi sebagai anak keturunan bangsawan karena telah melanggar adat dan membawa aib keluarga. Kedatangan Telaga di tempat ibunya, atas permintaan ibu Wayan dalam melakukan upacara, sehingga permintaan inilah yang menjadi pertimbangan Ibu Telaga dalam menerima Telaga hanya untuk melakukan upacara demi menjadi perempuan Sudra.

"Tiang tahu ini sulit dilakukan. Karena menyangkut harga diri Tukakiang dan nama baik griya. Dengan memberi kebebasan tiang bersembahyang dan pamit di pemerajan griya, tiang akan dijadikan contoh, akan menimbulkan masalah, karena akan banyak Ida Ayu yang kawin dengan laki-laki Sudra. Ini aib bagi mereka!"

"Sejak lama tiang berusaha mengerti apa artinya menjaga nama baik. Apalagi yang diinginkan mertuamu?"

'Dia ingin tiang melakukan upacara patiwangi sesuai kata- kata balian yang dia temui. Sebelum tiang melakukan upacara itu, tidak akan ada ketenangan. Tiang dianggap membawa malapetaka. Pembawa sial!" (Rusmini, 2013:170).

Pelaksanaan upacara itu pun diizinkan oleh keluarga Telaga di griya. Telaga pamit pada leluhur dan melakukan upacara demi menanggalkan nama Ida Ayu untuk menghindari kesialan dalam hubungan kekerabatan baginya dan anak-anaknya kelak.

"Telaga duduk, berusaha membuka seluruh konsentrasinya. Beragam sesaji tergeletak dingin. Dupa, arak, dan bunga-bunga bersatu. Telaga menebus kelahirannya.

Masih satu upacara yang harus dilakukannya agar benar-benar menjadi perempuan Sudra. Patiwangi. Pati berarti mati, wangi berarti keharuman. Kali ini Telaga harus membunuh nama Ida AYu yang telah diberikan hidup padanya. Nama itu tidak boleh dipakai lagi. Tidak pantas. Hanya membawa kesialan bagi orang lain! (Rusmini, 2013:172).

Upacara yang dilaksanakan ini bagi tradisi Bali adalah sebagai bentuk penurunan derajat kebangsawanan menjadi perempuan Sudra. Perempuan Sudra yang dilakoni oleh Telaga menjadi pilihannya sendiri karena kekuatan cintanya kepada lelaki Sudra sehingga ia rela menanggalkan derajat kebangsawanannya menjadi perempuan Sudra. 
"Telaga bergumam, membiarkan perempuan tua itu mencuci kaki di ubun-ubunya untuk menjelmakan dirinya menjadi perempuan baru. Perempuan Sudra. (Rusmini, 2013:175).

Bagi Telaga, perempuan Sudra menjadi kebahagiaan tersendiri baginya karena harus berkorban demi mendapatkan cinta yang tulus dari Wayan. Pengorbanan ini sebanarnya demi cinta yang sering didengar oleh Telaga dari neneknya bahwa cinta yang tulus justru akan ada kebahagiaan tersendiri.

Telaga merasa orang-orang selalu lebih tahu daripada dirinya. Padahal, mereka sama sekali tidak tahu seperti apa perasaan Telaga ketika kawin dan hidup sebagai perempuan Sudra untuk yang pertama kalinya. Wayan hanya bisa membelikan kebaya dan kain yang kasar. Telaga benar-benar melatih diri untuk menanggalkan seluruh busana kebangsawanannya. Semua untuk cinta. Untuk perhatian, untuk kasih sayang yang tidak pernah dia dapatkan dari lakilaki (Rusmini, 2013:149).

Perasaan cinta Telaga terhadap Wayan menjadi bukti pengorbanan Telaga dalam mendapatkan cinta yang tulus dari lelaki. Permasalahan keluarga sering ia jumpai dalam perkawinan yang hanya mengutamakan pada sistem kekerabatan yang sekasta sehingga mendatangkan penderitaan, yang justru kebahagiaan tidak didapatkan. Hal tersebut dialami oleh Nenek Telaga, yang mau dinikahi dengan keturunan bangsawan, sehingga cinta sejati tidak diperoleh. Begitu pun dengan ibunya, yang pada awalnya adalah perempuan Sudra, karena ingin dihargai seperti orang bangsawan, memlih menikah dengan keturunan Brahmana, sehingga ibu tidak pernah memperoleh cinta yang tulus dari suaminya. Sistem kekerabatan masyarakat Bali yang mengutamakan pada kasta atau sederajat, ditentang oleh Telaga yang memilih menikah dengan lelaki Sudra, sehingga hukum adat pun ia lalui dengan menanggalkan seluruh kebangsawanannya dengan menjadi perempuan Sudra.

Masyarakat Bali menggunakan hukum patrilineal (garis bapak, laki-laki yang berkuasa), suatu prinsip keturunan yang menghitung hubungan kekerabatan melalui garis laki-laki saja. Oleh karena itu, bagi seorang individu semua kaum kerabat ayahnya dianggap sebagai anggota kelompok kekerabatannya, sedangkan kaum kerabat ibunya berada di luar kelompok kekerabatannya. Dalam pewarisan, yang berhak memperoleh harta warisan hanya anak laki-laki saja, sedangkan anak perempuan akan mendapat warisan melalui keluarga suaminya. Pernikahan yang bersifat endogami klen (clan), berarti pernikahan sedapat mungkin dilakukan di antara warga 
seklen (Hidayah, 1996:37-38). Dalam novel Tarian Bumi, tampak bahwa sistem kekerabatan masyarakat Bali digambarkan bersifat patriliniel. Hal tersebut digambarkan melalui tokoh utama Telaga yang berketurunan Brahmana yang menikah dengan Wayan sebagai seorang Sudra, sehingga Telaga harus mengikuti garis keturunan Wayan begitu juga pada anak-anaknya yang kelak menjadi seorang Sudra. Oleh karena itu, Wayan memiliki ahli waris yang diteruskan pada Telaga karena adik Wayan yang sudah menikah. Hal tersebut tampak pada kutpan berikut.

Menurut adat Bali, perempuan memang tidak memiliki hak waris. Kalau Sadri tidak kawin, dia memang punya hak lebih tinggi dari Telaga, iparnya. Tetapi sekarang Sadri sudah kawin. Otomatis hak itu jadi milik Telaga (Rusmini, 2013:158).

Pernyataan tersebut mengindikasikan pada adat Bali yang memegang sistem patriliniel dalam kekerabatan, dimana garis keturunan ayah yang menentukan silislah keluarga. Sistem kekerabatan begitu jelas diuraikan melalui beberapa tokoh, yakni Tokoh Luh Sekar yang berubah nama menjadi Jero Kenanga ibu dari Telaga, yang berasal dari Sudra menikah dengan Ida Bagus Ngurah sebagai lelaki Brahmana, sehingga Jero Kenanga mengikuti suaminya dan melahirkan anak bernama Ida Ayu Telaga yang berketurunan Brahmana. Perkawinan anaknya Ida Ayu tidak sesuai dengan adat, melalui pernikahan dengan Wayan Sasmitha yang istilahnya diculik karena dilarang pernikahan antara perempuan Brahmana dengan lelaki Sudra, sehingga Telaga harus keluar dari kebangsawanannya dengan mengikuti suami menjadi perempuan Sudra. Dari perkawinan mereka, lahirlah Luh Sari perempuan Sudra yang mengikuti garis ayahnya. Namun, sebelumnya untuk menjaga sistem kekerabatan sekasta, tampak pada nenek Telaga yakni Ida Ayu Sagra Pidada, yang dinikahi oleh orang tuanya dengan yang sekasta yakni Ida Bagus Tugur, meskipun melalui nyentana sehingga neneknya yang lebih berkuasa penuh atas kakeknya. Sistem kekerabatan tersebut tampak pada silisilah tokoh utama yang terdapat dalam novel Tarian Bumi Karya Oka Rusmini berikut. 


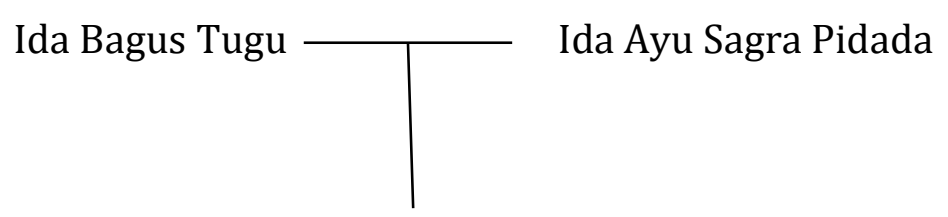

Ida Bagus Ngurah Pidada $\longrightarrow$ (Jero Kenanga)
Wayan Sasmitha $\longrightarrow$ Ida Ayu Telaga Pidada

Luh Sari

(Rusmini, 2013:176).

Berdasarkan silislah tersebut, semakin memperjelas bahwa sistem kekerabatan masyarakat Bali berdasarkan sistem patrilineal sehingga status ditentukan oleh garis keturunan laki-laki.

\section{SIMPULAN}

Berdasarkan hasil penelitian dapat disimpulkan bahwa sistem kekerabatan masyarakat Bali dalam novel Tarian Bumi karya Oka Rusmini adalah sistem kekerabatan patrilinieal. Patrilineal yang ditunjukkan dalam novel ini melalui perkawinan sekasta, karena sudah menjadi hukum adat Bali seorang perempuan Brahmana harus menikah dengan laki-laki Brahmana agar tidak terjadi malapetaka dan aib bagi keluarga.

\section{REFERENSI}

Bagus, I Gusti Ngurah. (2010). Kebudayaan Bali. Jakarta: Djambatan.

Endraswara, Suwardi. (2008). Metodologi Penelitian Sastra.Yogyakarta:

MedPress. .(2015). Metodologi

Penelitian Antropologi Sastra.

Yogyakarta: Ombak.

Hermaliza, Essi. (2011). Sistem Kekerabatan Suku Bangsa Kluet di Aceh Selatan The kinship System of Kluet Etnics in South Aceh. Jurnal Widyariset, Vol. 14 No.1, 2011 Hal. 123-132.

Hidayah, Zulyani. (1996). Ensiklopedi Suku Bangsa di Indonesia. Jakarta: LP3ES.

Koentjaraningrat. (2000). Pengantar Ilmu Antropologi. Jakarta: Radar Jaya Offset. . (2002). Pengantar Ilmu Antropologi. Jakarta: PT Rineka Cipta. . (2015). Pengantar Ilmu Antropologi. Jakarta: PT Rineka Cipta. Ratna, Nyoman Kutha. (2007). Teori, Metode, dan Teknik Penelitian Sastra. Yogyakarta: Pustaka Pelajar. . (2011). Antropologi

Sastra: Peranan Unsur-unsur Kebudayaan dalam Proses Kreatif. Yogyakarta: Pustaka Pelajar.

Rusmini, Oka.(2013). Tarian Bumi. Jakarta: PT Gramedia Pustaka Utama. 
Siany L, dan Catur Atiek B. (2009). Khazanah Antropologi 1. Jakarta: Pusat Perbukuan, Departemen Pendidikan NAsional.

Sudikan, Setya Yuwana. (2007). Antropologi Sastra. Surabaya: Unesa University Press. Oka Rusmini.

Turaeni, Ni Nyoman Tanjung. (2015). "Nyentana" Sistem Perkawinan dalam Novel Tarian Bumi Karya Oka Rusmini. KEMBARA: Jurnal Keilmuan Bahasa, Sastra, dan Pengajarannya, Oktober 2015, Volume 1, Nomor 2, hlm 233-238. http://ejournal.umm.ac.id/index.php/kem bara/article/view/2619/3270 